\title{
Research Article Online Learning in the Time of Crisis: A Study of EFL Students' Attitudes
}

\author{
Mustafa Fuzi Elshawish1, Jalal Ali Belshaikh² \\ ${ }^{1}$ Misurata University, Libya \\ ${ }^{2}$ Tripoli University, Libya
}

\begin{abstract}
This article discussed the importance of utilizing online learning during times of crisis, with special emphasis on the situation in Libya where this research took place. In spite of the dangerous current situation, i.e. the widespread of a deadly Coronavirus, academic bodies (schools, universities, academies) in Libya are still relying on basic methods of learning, i.e., adopting the essential way of person-to-person classes and meetings. Although there have been some attempts at using blended learning, most of the institutions are persist with old methods. The current situation in the country since the beginning of the unrest in 2011 and recently with the emergence of a serious disease (i.e., COVID-19) shook the whole country and demanded urgent intervention. However, because of the fragile situation and the decaying infrastructure in Libya, challenges to the education system are huge. The present researchers find it crucial to conduct this investigation due to the significance of e-learning courses during crises. This article highlights the perceptions of a group of postgraduate students of English on online learning and also includes the Advantages, Disadvantages, Opportunities, and Barriers (ADOB) study of the e-learning approach in the time of crisis. The results revealed that access to e-learning in Libya was hindered by many challenges, and consequently, students perceived online learning as inefficient. The paper also provided some recommendations for educational bodies which could help in how to deal with issues related to online learning.
\end{abstract}

Keywords: education, technology, online learning, Coronavirus, COVID-19, Libya

This is an open access article under the CC-BY-NC license.

\section{INTRODUCTION}

Crises around the world, whether natural such as earthquakes, hurricanes, floods or pandemics or man-made such as wars and other conflicts, have become commonplace. These crises have not only affected the global economy but also the education sectors in many countries around the globe. The most recent natural crisis is the worldwide spread of the Coronavirus: COVID-19. Most governments around the world have temporarily closed educational institutions in an attempt to stop its spread. These nationwide closures are impacting over $91 \%$ of the world's student population (UNESCO 2020). Being part of this world, Libya has sustained serious drawbacks and extensive infrastructural damage in education as well as in many other sectors, especially during the period of unrest since the uprising against the former regime in 2011. Libya is now facing major difficulties, and in order to deal with this natural crisis (i.e., COVID-19 pandemic) and overcome the difficulties of implementing virtual classes, the country needs to provide a stable electricity supply and reliable Internet access, which are prerequisites for implementing any e-learning programs. Due to the above-mentioned drawbacks, schools, universities, and academies in Libya presently depend only on traditional ways of teaching, i.e., they adopt the typical

Corresponding author:

mustafa.elshawish@art.misuratau.edu.ly

DOI: https://doi.org/10.31098/jefltr.v1i2.650

Research Synergy Foundation 
set up of person-to-person in classrooms. In spite of the fact that some of the academic institutions have also begun blended learning, still, many of them are stuck with the traditional methods.

As per some investigations, it is still unclear when to return to regular education. According to some WHO reports, this situation (i.e., COVID-19 Pandemic) may last for an unpredictable period of time. As social distancing becomes a must in the current phase, this would have undesirable consequences on learning chances unless certain rapid steps took place. Educational departments in every country are racing against time to find alternatives. These circumstances make us realize that scenario planning is an urgent need for academic institutions (Rieley, 2020). There is an urgent need to protect our students, members of staff, and the entire community, and at the same time to keep the educational processes on track.

\section{LITERATURE REVIEW}

\section{E-learning}

Technology has made possible the field of distance education via e-learning. E-learning, online learning and distance learning are considered modern options of learning. E-Learning means learning delivers electronically. It allows students to take courses online using electronic devices such as computers or smartphones. Learners interact with their teachers only through the internet. There is no personal connection or touch. Distance learning is very much like traditional education. It covers almost all degree levels and subjects often delivered online. Students in distance learning will be taught by lectures, receive guides by tutors, discuss with classmates, take exams; however, without the constraints of physical presence and strict schedules. With distance learning, students can learn at their own speed from anywhere at any time. On the other hand, online learning allows the students to use a virtual classroom through conference software like Zoom, Cloud Meeting etc., to connect and interact with their teacher face-to-face along with learning online through the internet. Hence, the traditional method of teaching, which requires the presence of a teacher in front of a group of students inside a classroom, cannot be the only option available for learning: many other learning methods exist now.

Cojocariu et al. (2014) claim that most forms of e-learning such as online learning, open learning, web-based learning, computer-mediated learning, blended learning, m-learning, have in common the need for a computer connected to a network that offers the possibility to learn from anywhere, anytime, in any rhythm, by any means. E-learning can be considered an instrument that can make teaching-learning processes more student-centered, more interesting, more advanced, and also more innovative. Moore and Kearsley (1996) define distance learning as a learning environment where "students and teachers are separated by distance and sometimes by time" (p. 1). Rovai, Ponton, and Baker (2008) emphasize that if any element in structured learning is separated by 'time and/or geography' (p. 1), then the learning is said to take place in a distance learning setting. Curran (2008) defines online education as a process by which students and teachers communicate with one another and interact with course content via Internet-based learning technologies. A course is considered an online course if $80 \%$ or more of the content is delivered via the Internet (Simonson, Smaldino, Albright, \& Zvacek, 2009). Moreover, online learning is defined as "learning experiences in synchronous or asynchronous environments using different devices (e.g., mobile phones, laptops, etc.) with Internet access. In these environments, students can be anywhere (independent) to learn and interact with instructors and other students" (Singh \& Thurman, 2019).

145

ISSN 2776-4524 (Online) | 2776-4184 (Print) 


\section{Synchronous vs Asynchronous Learning}

In the world of online education, often known as distance learning, classes can be synchronous or asynchronous. Synchronous distance learning happens when the tutor and students engage in the learning process while they are far away from each other. Learners registered in synchronous courses are normally asked to log on to their computers during a set time at least once a week. Synchronous distance learning may include multimedia components such as group chats, web seminars, video conferencing and phone call-ins (Littlefield, 2018).

Asynchronous distance learning, on the other hand, happens when the instructor and the learners act in different spaces and at different times. In other words, learners who are engaged in asynchronous courses have the ability to finish the task any time they wish. Asynchronous e-learning usually depends on technology such as email, e-courses, online forums, audio recordings and video recordings (Littlefield, 2018).

\section{Online Learning in Libya}

Libya is a North African country and part of the Arab world with a population of around 7 million. The country has been a site of constant instability for decades culminating in unrest in the year 2011 when an uprising against the former totalitarian regime started. Since the beginning of that uprising, the country has witnessed many conflicts that resulted in serious abuses, destruction of properties, and extensive damages to the infrastructure. Moreover, because of those continuous conflicts, the country has been in a state of total chaos and instability, and all lively sectors of the state, including education and the economy, have been negatively affected. In fact, this new norm caused huge disruption in educational processes, and the country became more vulnerable to natural disasters and manmade conflicts.

Generally speaking, the use of the Internet in the daily life of Libyan people started in the late 1990s and early 2000s, but with very little concern for educational purposes. All classes at the time were still conducted with face-to-face setups, with little use of technology besides overhead projectors or film slides.

However, the recent crisis is in the form of the global COVID-19 pandemic has spread like wild fire and caused a state of total chaos in Libya. Most schools, universities and academies have faced lockdowns in an attempt to stop the spread of the virus. Different educational establishments are, therefore, looking to use e-learning so that education can continue unhindered. Yet, in the current situation, e-learning across Libya can be interrupted by many technical issues such as frequent power cuts and poor Internet access. In other words, the country faces severe limitations because of its inadequate IT infrastructure. Proper IT infrastructure is a prerequisite for online learning. Infrastructure should be strong enough that it can afford good services during the pandemic and beyond.

\section{Significance of the Study}

In Libya, online learning, whether in schools, universities or academies, has been poorly approached or applied. This article helps to improve the general understanding of online learning in Libya. It looks at the benefits and the drawbacks of online learning during the pandemic. The results of the study will directly benefit postgraduate students doing MA in Applied Linguistics at the Academy of Postgraduate Studies in Misurata. It may also lead many institutions and schools to effectively implement online learning. This study signifies the urgent need to further study the perception of online learning in conflict zones. 


\section{Objectives of the Study}

1. To explore student perceptions of online learning in a Libyan context.

2. To conduct an Advantages, Disadvantages, Opportunities, \& Barriers (ADOB) study of e-learning approach in a time of crisis.

3. To give different educational institutions some suggestions and recommendations about online learning.

\section{Research Questions}

The research questions are as follows:

1. How do Libyan postgraduate students of English perceive online learning during a time of crisis?

2. What are the advantages, disadvantages, opportunities, and barriers associated with online learning during the COVID-19 crisis?

\section{RESEARCH METHOD}

To meet the objectives of the study, we adopted a mixed-methods approach using data emerging from online students' interviews and a questionnaire. The researchers focused on the qualitative aspects of the investigation for this paper.

\section{Participants}

Participants of the current study were fifteen students enrolled in the English department in the Academy of Postgraduate Studies in Misurata in the academic year 2020-2021. These students were invited to participate in the online study. They were reassured that their participation in the study would have no effect on their course results. Not all students who were invited agreed to participate, however. The fifteen participants who agreed to take part were broadly representative of the students in higher education in Libya.

Table 1: Demographic characteristics of participants

\begin{tabular}{lc}
\hline Personal information & Number \\
\hline Gender & \\
Male & 4 \\
Female & 11 \\
Total & 15 \\
Modules completed (out of 10)* & \\
Two Modules & 9 \\
Five Modules & 3 \\
Seven Modules & 2 \\
Nine Modules & 1 \\
Total & 15 \\
\hline
\end{tabular}

*Students have to complete 10 modules before they can start their MA dissertation

\section{Procedure}


Fifteen postgraduate students from Libya were recruited regardless of whether they had experienced online learning or not. A letter of consent was sent to the randomly chosen participants, and the researchers arranged appointments with them in order to run the interviews, which were conducted in English (see Appendix A), using the "WhatsApp" application. After completing the interviews, students were sent a survey via email (see Appendix B).

\section{Data analysis}

The recorded interviews were transcribed verbatim by the researchers and were checked many times to confirm the precision of each transcription. Pseudonyms (S1-S15) were used to ensure confidentiality. Responses to the questionnaire items were analyzed holistically due to the small size sample $(\mathrm{N}=15)$, (see Table 2).

\section{RESULTS AND DISCUSSION}

This study explored the perceptions and experience of online learning of a group of students enrolled in different courses within the department of English at The Academy of Postgraduate Studies, Misurata. It shed light on the importance of online learning in a time of crisis. In particular, this study aimed to: a) explore student perceptions of online learning in a Libyan context, b) conduct an Advantages, Disadvantages, Opportunities, \& Barriers (ADOB) study of e-learning approach in a time of crises.

\section{ADOB Analysis of Online Learning Advantages of Online Learning}

The majority of students agreed that online learning is advantageous during the COVID-19 pandemic. In the interview, S3 mentioned that the greatest benefit of e-learning was the flexibility it offered in terms of time and location. She said: "The lockdown of places and the unsafe commuting by roads can cause a lot of troubles but e-learning will guarantee that our education will continue at our homes". Another student (S10) confirmed that online learning "allows a pressure free environment". No doubt that modern technology can provide innovative and reliable solutions during crises and help learners and teachers communicate and interact with each other without the need for face-to-face interactions. In this respect, S7 added,

"Online learning allows learners to work through the lesson plan at their own pace to ensure that they are really mastering the material before moving on to the next section [...] this noticed flexibility allows online learners to move through the course work at their own speed and get the most out of the work".

In terms of the students' learning outcomes with online learning, some of the participant's responses to the interview questions were quite positive. S10, for instance, stated that "Yes, studies have shown that online activity during classes improves students' ability to focus. Furthermore, the adaptive learning feature of online learning significantly improves individual learning outcome".

These excerpts correspond with some of the students' responses to the questionnaire items (see Table 2 below), and reflect the strengths of online learning as a student-centered process that offers much flexibility with regard to time and place, and enables instructors to arrange procedures and processes based on their students' needs. 


\section{Disadvantages of Online Learning}

In spite of the many advantages of online learning, some of the students (e.g., S5, S11, S12 and S14) had an impression that the lack of teacher-student and student-student interactions might negatively affect the effectiveness of online learning. S11, for example, said, "Students don't have the chance to meet peers and interact directly with teachers". Similarly, S12 stated that "The complete presence of the teacher in the classroom can give him a better ability to control the class and consequently can save more time and efforts". Another student, S14, also added, "Students who may be confused or have questions leaving them lagging behind if they are shy or when they miss the chance to ask because of the lack of direct interaction with the teacher".

S7, also talked about time management and said: "Online learning could be difficult as it requires a lot of time management along with great effort from the inspectors." She also added, "Compared to learning in a physical classroom, online classes seem more difficult because you don't get the hands-on learning like you do in a physical classroom".

These excerpts are in line with the student's responses to the questionnaire items illustrated in Table 2 below. Online learning has faced some criticism regarding its value, effectiveness, and quality. First, direct communication and human touch are lost. That is, the physical existence of an instructor and students inside a classroom can make the interaction more dynamic and more interesting. "Users can face many technical difficulties that hinder and slow-down the teaching-learning process" (Favale et al., 2020). Moreover, most of the students believed that learning outcomes in online learning would not be better than the face-to-face approach. Their responses to the relevant interview questions mainly focused on the problems associated with Internet access and network challenges as possible causes of negative outcomes.

Table 2: Students' responses to the questionnaire items

\begin{tabular}{|c|c|c|c|c|c|}
\hline & $\begin{array}{l}\text { Online is or } \\
\text { might be much } \\
\text { more effective }\end{array}$ & $\begin{array}{l}\text { Online is or } \\
\text { might be } \\
\text { somewhat more } \\
\text { effective }\end{array}$ & $\begin{array}{lll}\text { Online is } & \text { or } \\
\text { might } & \text { be } \\
\text { equally } & \\
\text { effective } & \\
\end{array}$ & 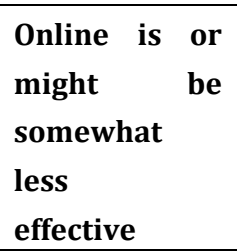 & $\begin{array}{l}\text { Online is or might } \\
\text { be much less } \\
\text { effective }\end{array}$ \\
\hline $\begin{array}{l}\text {...offering } \\
\text { convenience }\end{array}$ & $* * * * * * *$ & $* * *$ & ** & $* *$ & $*$ \\
\hline $\begin{array}{l}\text {...meeting } \\
\text { individual } \\
\text { learning needs } \\
\end{array}$ & $* * * * *$ & $* * * *$ & $* * * *$ & ** & \\
\hline $\begin{array}{l}\text {...contributing } \\
\text { to effective } \\
\text { communication } \\
\text { in the class } \\
\end{array}$ & ** & ** & $* * *$ & $* * * *$ & $* * * *$ \\
\hline $\begin{array}{l}\text {...increasing } \\
\text { your sense of } \\
\text { community } \\
\text { with the } \\
\text { instructor and }\end{array}$ & * & * & $* * * *$ & $* * * * *$ & $* * * *$ \\
\hline
\end{tabular}




\begin{tabular}{|l|l|l|l|l|l|}
\hline fellow students & & & & & \\
\hline $\begin{array}{l}\text {..promoting } \\
\text { greater student } \\
\text { participation } \\
\text { and interaction }\end{array}$ & $* * *$ & $* * *$ & $* *$ & $* * * *$ & \\
\hline
\end{tabular}

The symbol '*', indicates the number of students who responded to the questionnaire item.

\section{Opportunities}

In Libya, educators and instructors have usually been complacent and seldom sought new modes of learning. "Teachers have become habitual to traditional methods of teaching in the form of face-to-face lectures, and therefore, they hesitate in accepting any change" (Dhawan, 2020, p. 13). However, the emergence of the COVID-19 pandemic has forced educators to use new methods of teaching in order to continue educating students during this crisis. Thus, education could be improved with the exceptional increase of online learning whereby teaching is performed distantly and on digital platforms. This change would, of course, increase the need for educators to take further steps in order to cope with the new situation. In Libya, teachers, for example, are not all familiar and comfortable with modern technology; hence, many need to be trained. Moreover, as mentioned above, applying this new mode of learning requires more sophisticated facilities and equipment on the part of the education institutions.

With this sudden shift away from conventional teaching, the question might be asked whether this trend towards greater integration of online learning will continue even after the pandemic, and how such a shift would influence educational standards. Some participants of the current study believed that a new hybrid model of education would emerge, with important benefits. "I think that the insertion of technology into education will be even faster and that online learning will finally become an essential element of school education", explained S8. S5 added:

"E-learning will never fully replace classroom learning, rather save your money and time and allows you to share with as many employees you need. Also, it is not constrained with a date and time".

For those who have access to the right technology, online learning can be more effective in a number of ways. Students can learn faster online than in a traditional classroom setting, for they can learn at their own pace, going back, checking and re-reading, avoiding, or accelerating through concepts as they choose.

\section{Barriers}

Among the barriers identified by students were: inadequate infrastructure, lack of reliable Internet connection, and electricity supply issues. Internet access was one of the most frequently mentioned barriers by students. S2, for instance, mentioned that "bad Internet access is the most difficult part, especially when it comes to downloading or uploading materials". Moreover, S7 added, "The frequent electricity cutoffs can be considered the worst especially when the weather is so hot or so cold". S1 emphasized the same barriers saying: "Internet is not always available. As well as, in our country, there is always power outage". She also added: "Most of learners don't know how to deal with technology devices." Another student, S4, said that the absence of qualified teachers might be another barrier to 
online learning. Some of the teachers have no practical knowledge or enough experience with online learning, which added to the constraints of online education (cf. Olesova, Yang, \& Richardson, 2011). S6 explained: "Online learning is inaccessible to the computer illiterate population". However, another student, S11, blamed other factors for the inconvenience of online learning:

Online learning can have many barriers. I think students still prefer classroom classes over online classes due to many problems they face when taking online classes, such as lack of motivation, understanding of the material, and decrease in communication levels between the students and their instructors and their feeling of isolation caused by online classes.

Studying at home is not an easy task for some students, especially those with low motivation. Students can be motivated to put in more effort by hard-working and highly motivated peers. Besides, some homes often lack the necessary equipment and connectivity, and this issue can even demotivate the good learners, let alone the poor ones.

Most of the obstacles related to online learning surfaced by the literature review were found in the Libyan situation. Prerequisites to the success of online learning are: Qualified teachers to conduct online courses, a persistent supply of electricity, good Internet connection, and smartphones and computers in homes.

Table 3: Overall students' attitudes towards online learning

\begin{tabular}{|c|c|c|c|}
\hline Advantages & Disadvantages & Opportunities & Barriers \\
\hline $\begin{array}{l}\text {-Convenience } \\
\text {-Time \& location flexibility } \\
\text {-Allows a pressure-free } \\
\text { environment } \\
\text {-Improves individual } \\
\text { learning outcome } \\
\text {-Learning at own pace } \\
\text {-Supports the student- } \\
\text { centeredness process }\end{array}$ & $\begin{array}{l}\text {-Less social interactions } \\
\text {-Less control on parts of } \\
\text { teachers } \\
\text {-Difficult to ask \& answer } \\
\text { questions by students } \\
\text {-Less time management } \\
\text {-Less hands-on experience } \\
\text {-Less communication and } \\
\text { human touch } \\
\text {-Technical difficulties }\end{array}$ & $\begin{array}{l}\text {-Scope for innovation \& } \\
\text { digital development } \\
\text {-Strengthen teachers } \\
\text { technical skills } \\
\text {-An inventive educational } \\
\text { approach }\end{array}$ & $\begin{array}{l}\text {-Inadequate ICT } \\
\text { infrastructure } \\
\text { - Digital illiteracy } \\
\text {-Lack of the necessary } \\
\text { equipment and connectivity } \\
\text {-Lack of motivation } \\
\text {-Technology cost }\end{array}$ \\
\hline
\end{tabular}

\section{CONCLUSION AND SUGGESTIONS}

The principal objective of this study was to explore students' perceptions of online learning in a Libyan context, and to conduct an Advantages, Disadvantages, Opportunities, \& Barriers (ADOB) study of e-learning approaches in a time of crises. Possible benefits and drawbacks of online learning were identified. Opportunities and some perceived barriers were also highlighted. Findings revealed that access to online learning in Libya is still problematic. As a consequence, students perceived online learning as inefficient. Although the online learning was a good initiative for the majority of students, they still preferred face-to-face lectures to online classes given the many challenges. The lack of a persistent supply of electricity in students' homes and inadequate Internet access have dissuaded institutions from pursuing online education, and this situation might also demotivate students and teachers alike. Teachers, 
equipped with at least basic ICT literary skills to run online courses, persistent supply of electricity, reliable Internet access, and the availability of other requirements that contribute to the success of online programs such as ICT devices are all prerequisites for the successful integration of online learning in educational institutions. Therefore, technological and infrastructure support from the government is urgently needed. A strong IT Infrastructure is essential for online learning, and a high level of preparedness is required so that reliable and sufficient availability of electricity is secured. The teaching staff are key factors for the inclusive and equitable provision of high-quality online education. They should have adequate knowledge, expertise, and capabilities to perform online instruction, and that calls for more flexible and active post-pandemic instructor education.

It is recommended that further research be conducted to investigate the effectiveness of online learning in different contexts, i.e. secondary or undergraduate levels of education, dealing with a larger group of participants and using a quantitative approach.

\section{Limitations}

The sample of the current study was small, and it covers only postgraduate students, which makes it difficult for the findings to be generalized. Other students from tertiary or secondary education were not included. Instructors were not part of the study, so their perceptions of online learning are missing.

\section{REFERENCES}

Arthur-Nyarko, E., \& Kariuki, M. G. (2019). Learner access to resources for eLearning and preference for eLearning delivery mode in distance education programmes in Ghana. International Journal of Educational Technology, 6 (2), 1-8.

Cojocariu, V.-M., Lazar, I., Nedeff, V., \& Lazar, G. (2014). SWOT analysis of e-learning educational services from the perspective of their beneficiaries. Procedia and-Social Behavioral Sciences, 116, 19992003.

Curran, C. (2008). Online learning and the university. In W.J. Bramble \& S. Panda (Eds.), Economics of distance and online learning: Theory, practice, and research (pp. 26-51). New York: Routledge.

DePaul, K. (2020). Can online learning mitigate rural schools' biggest challenges? Retrieved from https://www.gettingsmart.com/2020/02/can-online-learning-mitigate-rural-schools-biggestchallenges/

Dhawan, S. (2020). Online Learning: A Panacea in the Time of COVID-19 Crisis. Journal of Educational Technology Systems, 0 (0), 1-18.

Favale, T., Soro, F., Trevisan, M., Drago, I., \& Mellia, M. (2020). Campus traffic and eLearning during COVID19 pandemic. Computer Networks, 176, 107290.

Ivala, E. (2013). ICEL2013-proceedings of the 8th international conference on e-learning: ICEL 2013.Academic Conferences Limited.

Moore, M.G., \& Kearsley, G. (1996). Distance education: A systems view. Belmont, CA: Wadsworth.

Olesova, L., Yang, D., \& Richardson, J. C. (2011). Cross-cultural differences in undergraduate students' perceptions of online barriers. Journal of Asynchronous Learning Networks, 15(3), 68-80.

Rovai, A.P., Ponton, M.K., \& Baker, J.D. (2008). Distance learning in higher education: A programmatic approach to planning, design, instruction, evaluation, and accreditation. New York: Teacher's College Press. 
Simonson, M., Smaldino, S., Albright, M., \& Zvacek, S. (2009). Teaching and learning at a distance: Foundations of distance education (4th ed.). Boston: Allyn \& Bacon.

UNESCO (2020). COVID-19 Educational Disruption and Response.

https://en.unesco.org/covid HYPERLINK "https://en.unesco.org/covid19\%20/education" HYPERLINK "https://en.unesco.org/covid19\%20/education" response . Accessed 12 April 2021.

\section{Appendix A: \\ Interview questions}

153 
Your answers to the following inquiries will be valued.

1. What is the utmost advantage of online learning?

2. How can you evaluate the current models of ordinary teaching and learning, with a particular focus to their long-term sustainability? In other words, do you think online learning can be an ideal alternative to face-to-face learning?

3. Do you think students' outcomes would be better with online learning?

4. What is the utmost disadvantage of online learning?

5. Can you mention some of the barriers, if any, to effective online learning?

6. Can you give a brief account of your own experiences with online learning?

\section{Appendix B \\ Online Learning Survey \\ Dear Participant,}


Online Learning in the Time of Crisis: A Study of EFL Students' Attitudes

Online learning has become widely used in educational institutions round the globe. Whether you have experienced online learning or not, we are interested in hearing about your opinion.

Please choose the appropriate box regarding the effectiveness of online education compared to regular face-to-face teaching.

\begin{tabular}{|c|c|c|c|c|c|}
\hline & $\begin{array}{l}\text { Online is or } \\
\text { might be } \\
\text { much } \\
\text { more } \\
\text { effective }\end{array}$ & $\begin{array}{l}\text { Online is or } \\
\text { might be } \\
\text { somewhat } \\
\text { more } \\
\text { effective }\end{array}$ & $\begin{array}{l}\text { Online is or } \\
\text { might be } \\
\text { equally } \\
\text { effective }\end{array}$ & $\begin{array}{l}\text { Online is or } \\
\text { might be } \\
\text { somewhat } \\
\text { less } \\
\text { effective }\end{array}$ & $\begin{array}{lr}\begin{array}{l}\text { Online is } \\
\text { might or } \\
\text { much be } \\
\text { effective }\end{array} & \\
& \end{array}$ \\
\hline $\begin{array}{l}\text {...offering } \\
\text { convenience }\end{array}$ & & & & & \\
\hline $\begin{array}{l}\text {..meeting } \\
\text { individual } \\
\text { learning needs }\end{array}$ & & & & & \\
\hline $\begin{array}{l}\text { This...contributing } \\
\text { to effective } \\
\text { communication in } \\
\text { the class }\end{array}$ & & & & & \\
\hline $\begin{array}{l}\text {...increasing your } \\
\text { sense of } \\
\text { community with } \\
\text { the instructor and } \\
\text { fellow students }\end{array}$ & & & & & \\
\hline $\begin{array}{l}\text {...promoting } \\
\text { greater student } \\
\text { participation and } \\
\text { interaction }\end{array}$ & & & & & \\
\hline
\end{tabular}

Thank you,

Name: (optional)

Gender: (Male) (Female)

Semester: $(\ldots . .$. 